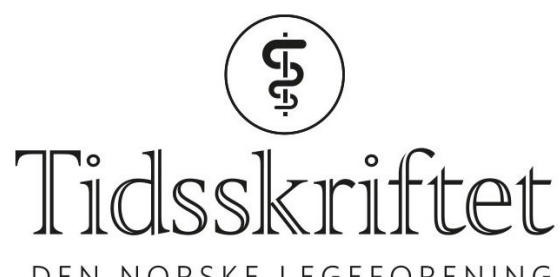

DEN NORSKE LEGEFORENING

\title{
Rettelse: Kosmetiske brystimplantater og brystkreft
}

RETTELSE

EMMA CAROLINE BEKKELUND SONDÉN

SOFIE SEBUØDEGÅR

CHRISTIAN KORVALD

JON LØMO

ELLEN SCHLICHTING

SIRI HELENE BERTELSEN BRANDAL

SOLVEIG HOFVIND

Tidsskr Nor Legeforen 2020; 140. doi:10.4045/tidsskr.19.0266.

I Tidsskriftet nr.3/2020 på s. 236 og 240 skal navnet på førsteforfatter være: Emma Caroline Bekkelund Sondén.

Vi beklager feilen, den er rettet på nett.

Publisert: 13. mars 2020. Tidsskr Nor Legeforen. DOI: 10.4045/tidsskr.20.0163

(C) Tidsskrift for Den norske legeforening 2020. Lastet ned fra tidsskriftet.no 